OPEN ACCESS

Edited by:

Amy Litt,

University of California, Riverside, USA

Reviewed by:

John E. Fowler,

Oregon State University, USA

Peter Karl Endress,

University of Zurich, Switzerland

Joseph H. Williams,

University of Tennessee, USA

*Correspondence:

José I. Hormaza

ihormaza@eelm.csic.es

Specialty section:

This article was submitted to Plant Evolution and Development,

a section of the journal

Frontiers in Plant Science

Received: 19 November 2015

Accepted: 20 January 2016

Published: 09 February 2016

Citation:

Lora J, Hormaza Jl and Herrero $M$

(2016) The Diversity of the Pollen

Tube Pathway in Plants: Toward an

Increasing Control by the Sporophyte.

Front. Plant Sci. 7:107.

doi: 10.3389/fp/s.2016.00107

\section{The Diversity of the Pollen Tube Pathway in Plants: Toward an Increasing Control by the Sporophyte}

\author{
Jorge Lora ${ }^{1}$, José I. Hormaza ${ }^{1 \star}$ and María Herrero ${ }^{2}$ \\ ${ }^{1}$ Department of Subtropical Fruit Crops, Instituto de Hortofruticultura Subtropical y Mediterránea La Mayora - University of \\ Málaga - Consejo Superior de Investigaciones Científicas, Málaga, Spain, ${ }^{2}$ Department of Pomology, Estación Experimental \\ Aula Dei, Consejo Superior de Investigaciones Científicas, Zaragoza, Spain
}

Plants, unlike animals, alternate multicellular diploid, and haploid generations in their life cycle. While this is widespread all along the plant kingdom, the size and autonomy of the diploid sporophyte and the haploid gametophyte generations vary along evolution. Vascular plants show an evolutionary trend toward a reduction of the gametophyte, reflected both in size and lifespan, together with an increasing dependence from the sporophyte. This has resulted in an overlooking of the importance of the gametophytic phase in the evolution of higher plants. This reliance on the sporophyte is most notorious along the pollen tube journey, where the male gametophytes have to travel a long way inside the sporophyte to reach the female gametophyte. Along evolution, there is a change in the scenery of the pollen tube pathway that favors pollen competition and selection. This trend, toward apparently making complicated what could be simple, appears to be related to an increasing control of the sporophyte over the gametophyte with implications for understanding plant evolution.

Keywords: pollen tube, sporophyte, gametophyte, pistil, evolution

\section{INTRODUCTION}

Alternation of generations between gamete-producing multicellular gametophytes and sporeproducing sporophytes is present in all land plants (Hofmeister, 1851). However, along the evolutionary line, the gametophytic phase gets reduced in terms of both size and lifespan compared to the sporophytic phase (Heslop-Harrison, 1975). In bryophytes the gametophytic generation is the more prominent phase and the sporophyte is nutritionally dependent on the gametophyte (Maciel-Silva and Porto, 2014). However, this situation is reversed in seed plants, in which the sporophyte is the prominent phase and the gametophytic generation is the one that develops and spends most of its life enclosed within the tissues of the sporophyte. Due to this prevalence of the sporophytic phase, often the implications of the gametophytic phase in plant evolution and domestication have been overlooked.

The mature pollen is the haploid microgametophyte. Mature pollen of gymnosperms is highly variable and can be formed by up to forty cells (Sterling, 1963; Pacini et al., 1999). However, a trend toward decreasing the number of cells could have appeared early in gymnosperm evolution (Sterling, 1963), probably linked to an evolutionary advantage related to a more efficient energy use (Pacini et al., 1999). In angiosperms, the mature male gametophyte is reduced to three cells, the vegetative cell and the two sperm cells. The female gametophyte (embryo sac) is generally formed by seven cells (two synergid cells, the egg cell, the central cell and three antipodal cells) 
embedded in the sporophytic tissues of the ovule. Interestingly, in spite of the wide morphological diversity observed for most traits and structures in the sporophytic phase of flowering plants, the development, structure, and function of the male and female gametophytes are very well conserved across angiosperm lineages.

However, clear differences in the subsequent contribution of the sporophytic tissues that envelop the female gametophyte and interact with the male gametophyte are observed along evolution. This is shown in the male-female meeting place where pollen germinates, and also along the pollen tube pathway toward the female gametophyte. All these steps have been widely studied in seed plants, but more extensively in angiosperms (Whitehead, 1969; Mulcahy, 1979; Eriksson and Bremer, 1992; Herrero, 1992; Hormaza and Herrero, 1992; Sargent and Otto, 2004), than in gymnosperms (Friedman, 1993, 2015; Owens et al., 1998; Gelbart and von Aderkas, 2002). In angiosperms, pollen germination and pollen tube growth takes place within the carpel that has been suggested to provide an opportunity for pollen competition and selection (Mulcahy, 1979; Hormaza and Herrero, 1992; Herrero and Hormaza, 1996; Taylor and Kirchner, 1996; Erbar, 2003; Lankinen and Green, 2015). However, variations in carpel structure are apparent along the evolution. Here we examine these differences, paying especial attention to the interaction between the male gametophyte and the female sporophyte during the different steps of the pollen tube pathway. We first examine the conservation of a pollen tube and then follow the pollen tube pathway, where a change in the meeting place and variations in the style and the ovary are observed. Finally, the implications of these variations during plant evolution are considered to get an integrated view on the evolutionary trends in the control of pollen tube performance in seed plants and the role of the sporophyte in this process.

\section{THE CONSERVATION OF A POLLEN TUBE}

A comparative review of the evolution of the male gametophyte (Friedman, 1993; Rudall and Bateman, 2007) shows that the most basal groups of extant gymnosperms, cycads, and Ginkgoales (Chaw et al., 2000), have multiflagellate sperms that swim to reach the archegonia [zooidogamy] (Friedman, 1990) whereas conifers (Fernando et al., 2005), Gnetales (Chaw et al., 2000) and angiosperms release non-motile male gametes through siphonogamy (Friedman, 1993). In fact, since the first pollen tube was observed by Amici (1824) in the angiosperm Portulaca oleracea in the early 19th century, pollen tubes were consistently observed in very different seed plant species. Evidence of microgametophyte tubes have also been observed in other plant taxa such as paleozoic seed ferns (Rothwell, 1972), where the tube was found in a chamber showing a branching pattern that can also be found in gymnosperms (Little et al., 2014). Thus, pollen tube development of Ginkgo biloba shows an initial tubular multiaxial form (Figure 1) (Friedman, 1987), cycad male gametophytes typically show unbranched pollen tubes although they can also be slightly branched (Friedman, 1987), and conifers show pollen tubes that can vary from unbranched to extensively branched (Fernando et al., 2005). Branching in gymnosperms has been suggested to have a haustorial role (Sterling, 1963; Little et al., 2014). In this sense, the heterotrophic pollen tube growth of most gymnosperms is associated with the degeneration of the invaded cells of the sporophyte by cellular outgrowth or enzymatic action. Thus, in gymnosperms, nucellar cell degeneration produced by pollen tube growth has been observed in Zamia furfuracea (Cycadaceae) (Choi and Friedman, 1991) and in Pseudotsuga menziesii (Pinaceae) (Owens and Morris, 1990). In angiosperms, heterotrophic pollen tube growth at the expenses of the stylar reserves was early documented (Herrero and Dickinson, 1979). Pollen tube branching has also been reported in several angiosperm species (Wilms, 1974; Hill and Lord, 1987; SmithHuerta, 1991; Johri, 1992; Sogo and Tobe, 2005), but no consensus on the cause or function of this branching has yet been reached. Non-mutually exclusive hypotheses include a haustorial role (Johri, 1992), a response to the clumping of pollen grains on the stigma (Smith-Huerta, 1991), interspecific (Williams et al., 1982), and intraspecific (Seavey and Bawa, 1986) incompatibility responses, or chalazogamy -the entrance of the pollen tube through the chalaza instead of the common way through the micropyle- (Sogo and Tobe, 2005, 2006b). But all these different situations may share a common ground: the absence of proper guidance signals for pollen tube growth from underdeveloped ovules (Herrero, 2000, 2001, 2003; Sogo and Tobe, 2006a).

Once the pollen tubes reach their target, fertilization takes place after the release of the male gametes from the pollen tube to the fertilization chamber in gymnosperms, or to the egg apparatus in angiosperms. Interestingly, morphological evidence suggests that the cytoskeleton of sperm cells and generative cells of angiosperms are closely related to the cytoskeleton of the flagellated sperm cells (Southworth and Cresti, 1997).

The Gnetales, with the exception of Welwitschia (Friedman, 2015), show some additional features that are also found in angiosperms. Thus, double fertilization occurs in Ephedra (Friedman, 1990; Friedman and Carmichael, 1996), and Gnetum displays a cell-cell interaction between the pollen tube and nucellar cells in an angiosperm-like fashion (Bell, 1995). Taken together this information, it appears clear that the construction of a pollen tube provides a prevalent useful way for the male gametes to travel toward the female gametophyte. But the landing site and the length of the pollen tubes in the different species are very variable, depending on the distance needed to travel to reach the targeted female gametophyte.

\section{CHANGING THE MEETING PLACE}

The first meeting point between the male gametophyte and the female sporophyte changes along the evolution of seed plants. Thus, in most gymnosperms, pollen lands in a pollination drop on the micropyle (Figure 1), which is reabsorbed with pollen and other air-borne particles (Gelbart and von Aderkas, 2002; Little et al., 2014). The situation is different in angiosperms in which a major synapomorphy is the presence of the ovule enclosed in a carpel (Endress and Igersheim, 2000). The carpel 

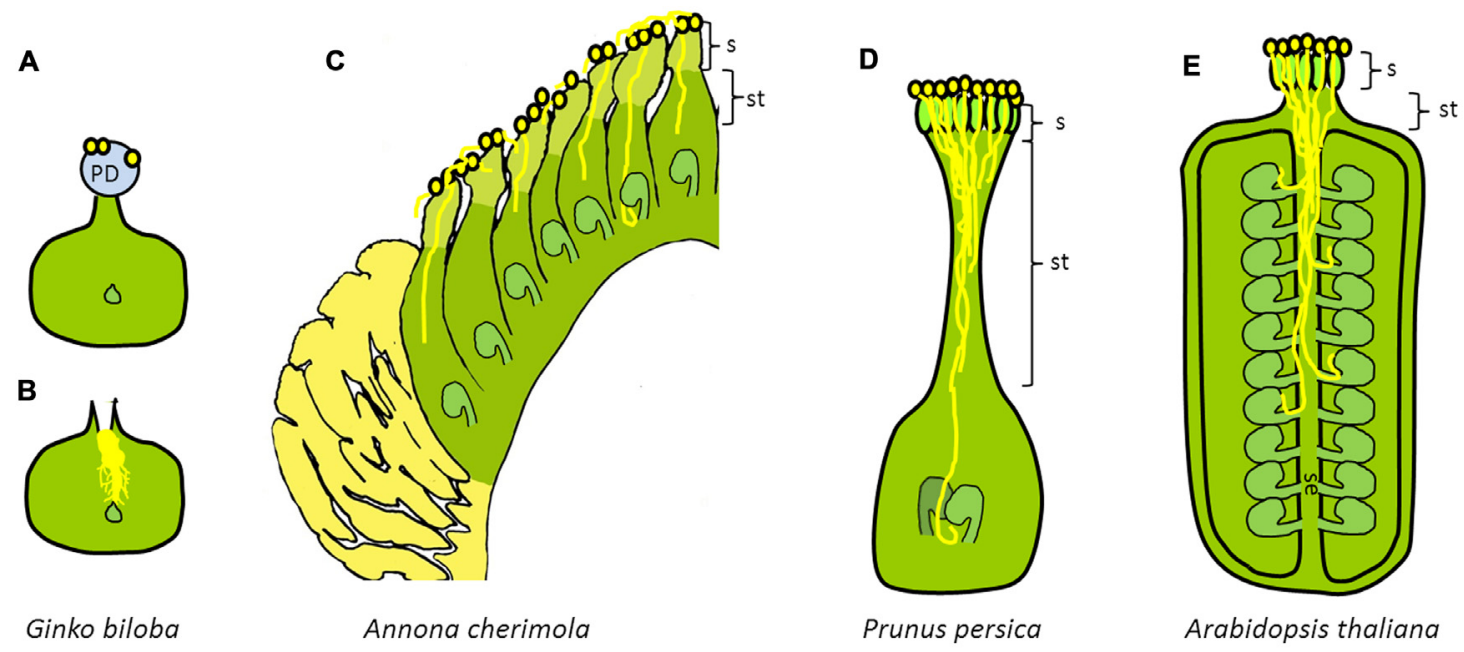

FIGURE 1 | Diversity of pollen tube pathways in seed plants. Schematic cross section of the gymnosperm carpel of (A,B) Ginkgo biloba, modified from Friedman (1987) and the angiosperm carpel of (C) Annona cherimola, (D) Prunus persica, and (E) Arabidopsis thaliana. (A,B) Gymnosperm carpel of (A) Ginkgo biloba showing the pollination drop and (B) pollination drop retraction with a branched pollen tube. (C) Angiosperm carpel of an early divergent angiosperm (Annona cherimola) showing extragynoecial compitum and unfused carpels (apocarpous). (D) Angiosperm carpel of an evolutionarily derived angiosperm (Prunus persica) showing pollen competition in the long style. (E) Angiosperm carpel of an evolutionarily derived angiosperm (Arabidopsis thaliana) showing pollen competition in the style and septum of a syncarpous gynoecium. PD, pollination drop; S, stigma; ST, style; SE, septum.

adds an additional envelope to the female gametophyte and also a different landing place for the pollen grain, the stigma (Figure 1).

In gymnosperms, the pollination drop is a viscous liquid secretion produced by the ovule, usually by the nucellar tissue (Gelbart and von Aderkas, 2002; Coulter et al., 2012), with the probable contribution of other tissues such as the megagametophyte and the integument (Owens et al., 1998). The pollination drop is composed of carbohydrates, amino acids, and a miscellany of other compounds (Gelbart and von Aderkas, 2002; Nepi et al., 2009; von Aderkas et al., 2015). Pollination drops are commonly found in Ginkgoales (Friedman, 1987), Cycadales (Choi and Friedman, 1991), Gnetales (Endress, 1996; Bolinder et al., 2015; Friedman, 2015; von Aderkas et al., 2015), and Pinales (Owens et al., 1998; Möller et al., 2000; Chandler and Owens, 2004), although no pollination drop seems to be produced in Abies, Cedrus, Tsuga, Pseudotsuga, or Larix in which pollen is drawn into the micropyle by collapse or inward growth of integument cells (Sedgley and Griffin, 1989). Captured pollen triggers a retraction of the drop that facilitates access of the pollen to the micropyle. While pollen from unrelated species can initiate the retraction of the pollination drop, the process is only completed by conspecific pollen (Mugnaini et al., 2007; Jin et al., 2012). Environmental conditions can significantly affect the success of pollination since the pollination drop can evaporate under low relative humidity conditions (Gelbart and von Aderkas, 2002). Conversely, the withdrawal of the pollination drop can be inhibited by high relative humidity (Mugnaini et al., 2007; Jin et al., 2012). In Pinaceae a pollination drop has not been identified and it has been proposed that rainwater could take its function (Owens et al., 1998; Leslie, 2010). Besides favoring or jeopardizing the production of the pollination drop, environmental factors may also provide clues for its production, as the situation recently reported in insect-pollinated Ephedra foeminea where the pollination drop is produced during the full moon of July (Rydin and Bolinder, 2015). Taken together, these observations suggest that the pollination drop, and hence a successful pollination in gymnosperms, is rather vulnerable to environmental conditions. In fact, in both angiosperms and gymnosperms, pollen capture is highly influenced by environmental factors (Heslop-Harrison and Heslop-Harrison, 1985; Heslop-Harrison, 2000); however, in angiosperms the situation changes, showing a higher involvement of the sporophyte in the process due to the presence of closed carpels.

In fact, in angiosperms pollen landing occurs in a highly specialized structure: the stigma. While several molecules such as surface esterases, arabinogalactan proteins (AGPs), low-esterified homogalaturonans, or glycoside hydrolases can be found in both stigma and pollination drops (Coulter et al., 2012) and could be analogous (Villar et al., 1984), the stigma represents a major evolutionary transition that provides adhesion, hydration, and germination media for the pollen grains (Sanzol et al., 2003; Hiscock, 2008). A number of factors, such as reactive oxygen species (ROS; McInnis et al., 2006; Allen et al., 2011; Traverso et al., 2013; Serrano et al., 2015) commonly proposed to mediate cell-cell communication (Gilroy et al., 2014), or surface esterases (Hiscock et al., 2002) contribute to this receptivity. In apple flowers, AGPs are secreted to the stigma concomitantly with the acquisition of stigmatic receptivity (Losada and Herrero, 2012) and their role supporting pollen germination is shown by the fact that they vanish following pollen germination. AGPs have been found in the stigma of several early divergent angiosperms (Prychid et al., 2011; Costa et al., 2013; Losada et al., 2014), and recent work shows that they also mark stigmatic receptivity in Magnolia (Losada et al., 2014), strongly suggesting that the 
secretion of AGPs could well be a conserved process in flowering plants marking stigmatic receptivity. Interestingly, AGPs were also reported in the pollination drop of the gymnosperm Taxus $x$ media (Coulter et al., 2012). Low-esterified homogalacturonans are also involved in the adhesion of the pollen to the stigma of angiosperms (Mollet et al., 2000) and seem to be play a role also in pollen grain adhesion in the gymnosperm Larix decidua (Rafińska et al., 2014). Glycoside hydrolases that are required for cell wall elongation and, consequently, for pollen tube growth, are found in both the angiosperm stigmas and the gymnosperm pollination drop, but expansins that are also involved in cell wall elongation are only found in the stigma of angiosperms (Coulter et al., 2012).

Stigmatic receptivity usually provides a short window of opportunity for pollination to be effective (Sanzol et al., 2003). This window is influenced by environmental factors, basically temperature at flowering (Hedhly et al., 2003, 2005b; Lora et al., 2011a; Sage et al., 2015). High temperatures accelerate stigma degeneration, whereas low temperatures maintain the stigma receptive for a longer time, affecting the effective pollination period (Sanzol and Herrero, 2001).

Once the pollen grains have germinated in the ovular pollination drop in gymnosperms or in the stigma in angiosperms, the pollen tube grows to reach the female gametophyte. The pollen tube pathway takes place surrounded by female sporophytic tissues and, consequently, with less environmental dependence but higher male-female interaction. Moreover, in angiosperms, this journey is further complicated by the presence of a new structure, the style.

\section{THE STYLE: MAKING A SHORT STORY LONG}

In most angiosperms, from pollen landing on the stigma to fertilization inside the ovary, the pollen tube has to traverse an intermediate territory, the style (Figure 1). The pollen tube grows through a stylar canal or a stylar transmitting tissue, and reaches the locule cavity of the ovary where the ovule is located. In the basal grade of angiosperms and magnoliids the style is very short or even absent and the stigma forms the margins of the sealed but unfused carpel in a continuum with the placenta leading to the ovule (Endress, 2015). Examples of these observations include basal angiosperms, such as Amborella trichopoda (Williams, 2009), Nymphaea capensis (Orban and Bouharmont, 1995), or Cabomba caroliniana (Galati et al., 2016), and magnoliids such as Annona cherimola (Lora et al., 2010, 2011a), Magnolia virginiana (Losada et al., 2014), or Saururus cernuus (Pontieri and Sage, 1999).

The stylar canal, or the stylar transmitting tissue, provides an extracellular secretion that is incorporated into the growing pollen tubes and allows a heterotrophic pollen tube growth (Labarca and Loewus, 1973; Herrero and Dickinson, 1979), that differs from the autotrophous pollen tube growth in the stigma (Herrero and Dickinson, 1981; Stephenson et al., 2003). This role of the pistil providing nutrients for the growing pollen tubes has been shown in a wide range of angiosperms including many fruit tree crops (Herrero and Arbeloa, 1989; Gonzalez et al., 1996; Martinez-Palle and Herrero, 1998; Alcaraz et al., 2010; Distefano et al., 2011; Suárez et al., 2013), and seems to be a conserved process in flowering plants. Secretion along the short style is also already present in basal angiosperms [Trimenia moorei, Illicium floridanum (Bernhardt et al., 2003), Kadsura longipedunculata (Lyew et al., 2007), or Amborella trichopoda (Thien et al., 2003)] as well as in early divergent angiosperms [Saururus cernuus (Pontieri and Sage, 1999), Psedowintera axillaris (Sage and Sampson, 2003), or Magnolia virginiana (Losada et al., 2014)]. The implication of different molecules in pollen-pistil interaction has been put forward with a role in providing adhesion and facilitating pollen tube growth through the transmitting tissue (Boavida et al., 2011; Chae and Lord, 2011; Palanivelu and Tsukamoto, 2012; Qu et al., 2015).

A number of different molecules that contribute to pollen tube building and guidance have been found in the style of angiosperms and a similar scenario has also been proposed in the gymnosperm Larix decidua (Rafińska et al., 2014). Concomitantly with pollen tube growth, an increase in the amount of calcium in the extracellular matrix has been observed (Lenartowska et al., 2001; Ge et al., 2009), which suggests the provision of an optimal calcium environment for polar pollen tube growth (Hepler et al., 2012; Steinhorst and Kudla, 2013). The role of calcium on pollen grain germination and pollen tube growth was also shown in conifers (Chen et al., 2008; Lazzaro et al., 2013). Suggesting complex needs for both gymnosperm and angiosperm pollen germination and tube growth. Other signals from the stigma and style, such as stigma/style cysteinerich adhesins (SCA) or chemocyanins, have also been shown in lily (Chae and Lord, 2011). While SCA are involved in pollen tube tip growth (Chae and Lord, 2011; Qu et al., 2015), chemocyanins appear to play a role in adhesion of the pollen tube to the stylar tissue (Park et al., 2000). Plantocyanins, blue copper proteins expressed also in the stylar transmitting tissue and homologs of chemocyanins, are also involved in pollen tube guidance, which is disrupted by plantocyanin overexpression in Arabidopsis (Dong et al., 2005). Experiments performed in maize also showed the sporophytic control of pollen tube guidance through the transmitting tissue that it is unaffected in RNAi-lines lacking functional embryo sacs (Lausser et al., 2010).

Recent studies have revealed the role of AGPs on pollen tube growth (Pereira et al., 2015) that have also been detected in the pollen tube tip of angiosperms (Qin et al., 2007; Dardelle et al., 2010). AGPs were observed in the stigma at pollination time in Magnolia (Losada et al., 2014), where a proper style is missing, and in olive (Olea europaea) (Suárez et al., 2013) that has a reminiscent style. Interestingly, in apple flowers which have a proper long style, AGPs were clearly present in the stigma but were not observed in the stylar transmitting tissue. Conversely, extensins that are involved in cell wall extension could not be detected in the stigma, but filled the style (Losada and Herrero, 2014). The clear boundary in two adjacent territories (stigma and style) of angiosperms, in which pollen tube kinetics are clearly different, suggests a support for faster pollen tube growth in the style. The remaining question is the possible meaning of this 
accelerated pollen tube growth in the style and the biological significance of the acquisition of a long style that requires the building up of a long pollen tube, making long, and complicated what could be a short and simple process.

A rapid pollen tube growth rate has been considered a key innovation of angiosperms (Williams, 2008). Thus, the whole process from pollination to fertilization can take several months in gymnosperms, which generally show slower pollen tube growth rates than angiosperms. An exception could be Ephedra, where a rapid fertilization has been reported (Land, 1907), but associated with a short pollen tube pathway and, consequently, a slow pollen tube rate similar to that observed in other gymnosperms (Williams, 2008). Rapid fertilization associated with a fast pollen tube growth rate was observed in the extant ANITA grade and magnoliids where pollen tubes penetrated the ovule in some 9-48 h after pollination (Bernhardt et al., 2003; Williams, 2008, 2012a,b; Lora et al., 2010).

However, in addition to the trend toward a faster pollen tube growth rate observed in seed plants, the process is also highly dependent on temperature (Hedhly et al., 2004; Coast et al., 2016). Thus, pollen tube growth is often slower in species adapted to temperate climates; for example, the progamic phase from pollination to fertilization takes three weeks in Prunus persica (Herrero and Arbeloa, 1989). Still, temperature cannot be the only factor influencing pollen tube growth rate since species flowering under similar temperatures have clear differences in the length of the progamic phase, as it occurs between peaches and apricots (Herrero and Arbeloa, 1989; Rodrigo et al., 2000). Most significantly, a slow pollen tube growth rate appears to be related to a delayed maturation of the pistil in the ovary (Herrero and Arbeloa, 1989).

\section{THE OVARY: A HIDDEN INTENSE INTERACTION AREA}

In both gymnosperms and angiosperms the seeds that will produce the next sporophytic generation develop from the ovules. In angiosperms, once the pollen tubes get to the base of the style, they face the ovary that encloses the ovule(s). Angiospermy, or the presence of a closed carpel, is considered a key innovation of angiosperms (Endress and Igersheim, 2000; Endress, 2015), although variations in the degree of closure of the carpel have been described (Endress and Igersheim, 2000), ranging from sealing by secretion without postgenital fusion to complete postgenital fusion with intermediate stages. In the ANITA grade, carpel sealing is usually without postgenital fusion (Endress and Igersheim, 2000). In the magnoliids Annona cherimola (Lora et al., 2010) and Magnolia virginiana (Losada et al., 2014), papillae along the suture line face each other in a zip like fashion, with secretion filling the gaps and the pollen tubes grow along this continuous zip that goes from the stigma down to the ovule. In more derived clades, the process is more complex and the pollen tube has to enter the ovary, where particular structures may protect this entrance (Herrero, 2000). In peach flowers, the obturator -a placental protuberance facing the ovule- regulates this access, since pollen tube growth is only possible when this structure enters a secretory phase (Arbeloa and Herrero, 1987). The obturator has also been described in basal angiosperms such as members of the Austrobaileyales (Kadsura longipedunculata) (Lyew et al., 2007), and early divergent angiosperms in the magnoliid clade [Annona cherimola (Lora et al., 2010) and Persea americana (Sedgley and Annells, 1981)], although its active role in promoting pollen tube passage was not observed. This may be related to a continuous secretion, as it occurs in Annona cherimola where secretion is continuous all along the suture line right from anthesis up to fertilization time (Lora et al., 2010). A similar situation has been recorded in kiwifruit flowers with obturators secreting right from anthesis up to fertilization time (Gonzalez et al., 1996), which occurred some 3 days after pollination. Conversely, in peach flowers, this process was much slower lasting for about three weeks (Herrero and Arbeloa, 1989), and this delayed growth was due to a slow basipetal maturation of the pistil. In this species, the obturator did not only act as a gate to open the access to the ovule, but also seemed to close it since, following the secretory phase and pollen tube passage, callose was layered down on the obturator, preventing additional pollen tubes to pass by (Arbeloa and Herrero, 1987).

In other species with chalazogamy a different structure with a similar role has been described. In pistachio (Pistacia vera), a chalazogamous species (Martinez-Palle and Herrero, 1998), concomitantly with the arrival of the pollen tubes to the base of the style, a protuberance (the ponticulus) develops in the uppermost area of the funiculus, filling the physical gap between the base of the style and the ovule (Martinez-Palle and Herrero, 1994). A ponticulus has also been described in other species of the Anacardiaceae such as mango (Mangifera indica) (Joel and Eisenstein, 1980; De-Wet et al., 1986; Bachelier and Endress, 2009). A similar situation has been described in Fagales, where, interestingly, in Juglans (Luza and Polito, 1991) both chalazogamy and porogamy -the entry of the pollen tube into the ovule through the micropyle- could be observed, depending on the developmental stage of the ovule. Chalazogamy has also been reported in hazelnut (Corylus heterophylla) that shows a delayed fertilization; in this case, the pollen tube grows through the chalaza 52 or 55 days after pollination and this could be related to the delayed development of the ovule whose ovule primordium was observed 20 days after blooming (Liu et al., 2014).

Sporophytic control of pollen tube growth is also observed in the integuments, which surround the nucellus that embeds the embryo sac forming the micropyle. Most angiosperms show bitegmic ovules compared to the single integument present in most extant and fossil gymnosperms (Herr, 1995; Endress, 2011; Lora et al., 2015). In evolutionarily derived angiosperms, the outer integument seems to be involved in providing cues for pollen tube guidance toward the embryo sac (Herrero, 2000, 2001, 2003). The role of the inner integument on pollen tube growth was also suggested by the Arabidopsis pop2 mutant that shows higher concentration of GABA in the inner integument associated to reduced pollen tube guidance (Palanivelu et al., 2003). Moreover, in Arabidopsis, a truncated version of a protein disulfide isomerase PDIL2-1, expressed in the sporophytic tissue 
with higher expression in the micropyle of mature ovules, affect ovule structure, and impede embryo sac development disrupting pollen tube guidance (Wang et al., 2008). In the Arabidopsis inner no outer (ino) mutant lacking the outer integument, pollen tubes wander in the ovary and rarely reach the micropyle, although this could also be related to the absence of the embryo sac (Skinner and Gasser, 2009), since synergid cells play a role on pollen tube guidance (Higashiyama et al., 2001; Higashiyama and Hamamura, 2008; Kessler and Grossniklaus, 2011). However, the situation was different in a similar ovule ino mutant in Annona squamosa (magnoliids), which showed pollen tubes targeting the micropyle (Lora et al., 2011b). Further work is required to elucidate if this was due to the presence of an embryo sac in these ovules or to a late recruitment of the outer integument for pollen tube guidance in angiosperms, since in this species as in other Annona species the outer integument is retracted and does not embrace the micropyle.

To date, several molecules have emerged as major players involved in the cell-cell communications between synergids/egg apparatus and pollen tube (reviewed in Higashiyama and Takeuchi, 2015; Qu et al., 2015) supporting the main role of the female gametophyte in pollen tube reception (Kessler and Grossniklaus, 2011). Examples of those molecules include the defensin-like polypeptide LUREs (Okuda et al., 2009) in Torenia, the homolog AtLURE1 (Takeuchi and Higashiyama, 2012), the transcription factor MYB98 (Kasahara et al., 2005), the FERONIA (Escobar-Restrepo et al., 2007), and, recently, TURAN and EVA (Lindner et al., 2015) in Arabidopsis, or ZmEA1 that is expressed in the egg apparatus of maize (Marton et al., 2005). Recent studies have also shown the role of ROS on pollen tube growth (Potocký et al., 2007) and on the rupture of the pollen tube and subsequent fertilization in Arabidopsis (Duan et al., 2014),

Although less work has been done in gymnosperms, studies on the composition of the pollination drop has shown similar components to those of the stigma and style (Coulter et al., 2012), suggesting an involvement of these molecules on pollen-pistil interaction. Additional functional studies for these molecules to show their putative role in pollen tube guidance or pollen tube reception are needed. Work in angiosperms converges to the point of a sophisticated pollen-pistil interaction all along the different pistil territories the pollen tube has to traverse. Yet the question remains on the significance of this interaction and why along evolution the pollen tube journey seems to gain in complexity and difficulty. This complexity appears to share a common ground: a bigger control of the sporophyte.

\section{TOWARD A MAJOR CONTROL OF THE SPOROPHYTE}

When comparing gymnosperms, basal angiosperms and evolutionarily derived eudicots, evolution seems to have complicated what virtually could be simpler. The continuous adding of layers to envelop the embryo sac complicates pollen tube growth that in angiosperms has to often grow long distances within the sporophytic tissues of the flower. In angiosperms, closed carpels provide opportunities for an intense pollen-pistil interaction, whereas in gymnosperms the main interaction of pollen with the female sporophyte takes place at the micropyle in the pollination drop (Figure 1). Mulcahy (1979) proposed that the combination of closed carpels (syncarpy) and insect pollination could increase the chances for male gametophytic competition and selection enhancing the ability of natural selection to act on the gametophytic phase of the life cycle of angiosperms helping to understand the adaptive success of flowering plants.

The presence of physical barriers, such as dichogamy, monoecy, dioecy, or floral heteromorphy, between the female and male parts to avoid self-fertilization have developed in both gymnosperms and angiosperms (Zavada and Taylor, 1986). Moreover, the rejection of pollen from unrelated species, or incongruity (Hogenboom, 1975), has been documented in both gymnosperms (Mugnaini et al., 2007; Jin et al., 2012), and angiosperms (Heslop-Harrison, 2000). It is difficult to understand how minute secretions allow discerning between conspecific and heterospecific pollen, since the basic ingredients of artificial pollen germination media are very similar for the different species. This discernment suggests a precise malefemale cross talk, right from the first encounter (McInnis et al., 2006).

More intriguing is the possible pollen selection in intraspecific matings. The most common way to avoid self-fertilization in angiosperms is self-incompatibility (SI) (de Nettancourt, 2001; Iwano and Takayama, 2012; Sawada et al., 2014). Although evidence of failure of pollen tube growth before fertilization has been reported in conifers (Kormutak, 1999; Takaso et al., 1996; Gelbart and von Aderkas, 2002), this is still a subject of debate (Little et al., 2014), and, in a good number of instances, selection against self-fertilization in gymnosperms appears to be related to post-fertilization events (Orr-Ewing, 1957; Hagman and Mikkola, 1963; Mergen et al., 1965; Williams et al., 2001; Owens et al., 2005).

In angiosperms, the evidence of SI is widespread, but the very different types of incompatibility recorded in different families suggest that SI has arisen de novo several times in independent lineages of flowering plants (Ferrer and Good, 2012; Gibbs, 2014). It is estimated that half of angiosperm species show SI (Dresselhaus and Franklin-Tong, 2013; Gibbs, 2014), but only in a few families has SI been characterized in detail. Three main types of SI have been described, sporophytic self-incompatibility (SSI), gametophytic self-incompatibility (GSI), and late actingself incompatibility (LSI). SSI has only been reported in six families (Gibbs, 2014) and seems to be restricted to eudicots (Allen and Hiscock, 2008); GSI has been reported in species of 18 families (Gibbs, 2014) and is the most abundant SI mechanism in flowering plants, present in all major clades of monocots and eudicots (Allen and Hiscock, 2008). Excellent recent reviews have addressed the evolution, diversity and molecular mechanisms of the different self-incompatibility systems (de Nettancourt, 2001; Takayama and Isogai, 2005; Franklin-Tong, 2008; Iwano and Takayama, 2012; Gibbs, 2014).

Different empirical evidence shows a high overlap in the genes expressed during the gametophytic and the sporophytic phases of the angiosperm life cycle (Ottaviano and Mulcahy, 
1989; Mascarenhas, 1990; Honys and Twell, 2003) as well as a correlation between higher pollen competition and selection and traits in the following sporophytic generation (Hormaza and Herrero, 1992, 1994). Pollen selection is highly dependent on pollen competition, and the pistil seems to be well devised to favor competition among growing male gametophytes (Hormaza and Herrero, 1992, 1994, 1996b; Herrero and Hormaza, 1996), starting by the promotion of an accumulation of a high number of pollen grains in the stigma. This allows the style to act as a long sieve, with a progressive reduction in both nutritive resources and space, that finally results in a reduced number of pollen tubes able to reach the ovary (Herrero, 1992). However, this situation appears to be different between the ANITA grade, magnoliids and eudicots. The stigmas of the ANITA grade and magnoliids show extragynoecial compitum that allows pollen tube growth between the stigmas of the different carpels (Endress and Igersheim, 2000; Williams et al., 2010; Lora et al., 2011a). Moreover, the carpels of he ANITA grade and magnoliids are generally separate (apocarpous) and show a short style (Orban and Bouharmont, 1995; Pontieri and Sage, 1999; Lora et al., 2010; Galati et al., 2016). As a consequence, the main competition among male gametophytes occurs in this extragynoecial compitum. In fact, extragynoecial pollen tube growth is widespread in apocarpous species (Wang et al., 2012). In contrast, most evolutionarily derived angiosperms (83\%) show fusion of the carpels forming a syncarpous gynoecium (Endress, 1982). The syncarpous gynoecium mostly has an intragynoecial compitum that provides more protection from adverse environmental conditions, and allows a more intense pollen tube competition and selection (Endress, 1982). This increased pollen competition is reinforced in evolutionarily derived angiosperms by the common presence of long styles that act as long sieves reducing basipetally both the space and the nutrients available for growing pollen tubes (Herrero and Hormaza, 1996; Distefano et al., 2011).

In theory, this gametophytic competition and selection should not be restricted to the male gametophytes but it is more difficult to prove in the female gametophytes. Nevertheless, recently, Bachelier and Friedman (2011) have shown the occurrence of gametophytic competition among female gametophytes within the single ovule in the early-divergent angiosperm Trimenia moorei. It will be of interest to analyze if this could be the case in other angiosperm lineages although, in any case, the likelihood of a significant selection pressure will always be higher in the male gametophytes due to their higher population number.

Although the presence of pollen competition in plants has been shown in a high number of cases (Hormaza and Herrero, 1994), it is still difficult to ascertain whether this competition finally results in selection for particular traits or adaptation to particular conditions that could result in a change in the gene frequencies of the next sporophytic generation (Baskin and Baskin, 2015). Evidence has been obtained mainly in two areas. Pollen behavior in response to different environmental factors has been shown to differ among different genotypes (Hormaza and Herrero, 1992; Hedhly et al., 2005a), and plants exposed to a selection pressure during the reproductive process may produce an offspring more adapted to these conditions than when the same crosses are performed under controlled conditions (Hormaza and Herrero, 1996a; Hedhly et al., 2009; Hedhly, 2011). Recent work using molecular approaches provides additional evidence that genome evolution could be affected by pollen competition. Thus, Arunkumar et al. (2013) showed in Capsella grandiflora that selection had more detectable effects on pollen-exclusive genes than on seedling-exclusive genes whereas Chettoor et al. (2014) observed that selective pressures based on the male gametophytic function result in high effects on the maize plant genome. Additional work assessing paternity of the offspring shows that pollen tube competition could also result in sexual selection in plants (Hedhly et al., 2015).

All this converges to the point that the pistil exerts a dual support/constrain strategy that may result in gametophyte competition and selection (Herrero and Hormaza, 1996). Thus the sporophyte supports pollen tube heterotrophic growth, but also promotes pollen competition and selection with spatial and nutritive constraints and with self-incompatibility systems that involve cell-cell recognition. In fact, if gametophytic selection is mainly based in the growth rate of pollen tubes, we would expect that the traits responsible for rapid pollen tube growth should be rapidly fixed in the populations. Sporophytic control would result in the fact that the best male-female combinations are favored providing an advantage to the best suited male gametophytes for a given female genotype which could explain why genetic variation for male gametophytic fitness has been maintained in plant populations (Herrero and Hormaza, 1996; Hormaza and Herrero, 1996a). In angiosperms the development of the carpel, while providing further protection for the female gametophyte and the seed, also gives an enhanced opportunity for male-female cross talk. This results first in a change in the meeting place from the pollination drop of gymnosperms to the secretory stigma of angiosperms. But, more interestingly, it also results in changes in the landscape that the pollen tube has to traverse to reach the megagametophyte. The style provides ample opportunity for pollen competition and selection, and the ovary shows a close control of pollen tube access to the ovule. This change in the territory that the pollen tube has to traverse along its journey results in a process more protected from external environmental factors, but also in the sporophyte gaining control over the gametophyte. As a result, the interaction between the gametophyte and the sporophytic tissues of the flower seems to be an arena with implications for plant diversity and evolution.

\section{AUTHOR CONTRIBUTIONS}

$\mathrm{JL}, \mathrm{JH}$, and $\mathrm{MH}$ wrote and reviewed the final version of the manuscript.

\section{ACKNOWLEDGMENTS}

This work was supported by Ministerio de Economía y Competitividad - European Regional Development Fund, European Union (AGL2012-40239, AGL2013-43732-R, and Recupera2020) and Gob. Aragón A-43. JL was supported by a Juan de la Cierva postdoctoral grant of the Spanish Ministry of Science and Innovation. 


\section{REFERENCES}

Alcaraz, M. L., Hormaza, J. I., and Rodrigo, J. (2010). Ovary starch reserves and pistil development in avocado (Persea americana). Physiol. Plant. 140, 395-404. doi: 10.1111/j.1399-3054.2010.01410.x

Allen, A., and Hiscock, S. (2008). "Evolution and phylogeny of self-incompatibility systems in angiosperms," in Self-Incompatibility in Flowering Plants, eds A. M. Allen and S. J. Hiscock (Heidelberg: Springer), 73-101. doi: 10.1007/978-3-54068486-2

Allen, A. M., Thorogood, C. J., Hegarty, M. J., Lexer, C., and Hiscock, S. J. (2011). Pollen-pistil interactions and self-incompatibility in the Asteraceae: new insights from studies of Senecio squalidus (Oxford ragwort). Ann. Bot. 108, 687-698. doi: 10.1093/aob/mcr147

Amici, G. B. (1824). Observations microscopiques sur diverses espèces de plantes. Ann. Sci. Nat. 2, 41-70.

Arbeloa, A., and Herrero, M. (1987). The significance of the obturator in the control of pollen tube entry into the ovary in peach (Prunus persica). Ann. Bot 60, 681-685.

Arunkumar, R., Josephs, E. B., Williamson, R. J., and Wright, S. I. (2013). Pollenspecific, but not sperm-specific, genes show stronger purifying selection and higher rates of positive selection than sporophytic genes in Capsella grandiflora. Mol. Biol. Evol. 30, 2475-2486. doi: 10.1093/molbev/mst149

Bachelier, J. B., and Endress, P. K. (2009). Comparative floral morphology and anatomy of Anacardiaceae and Burseraceae (Sapindales), with a special focus on gynoecium structure and evolution. Bot. J. Linn. Soc. 159, 499-571. doi: 10.1111/j.1095-8339.2009.00959.x

Bachelier, J. B., and Friedman, W. E. (2011). Female gamete competition in an ancient angiosperm lineage. Proc. Natl. Acad. Sci. U.S.A. 108, 12360-12365. doi: 10.1073/pnas. 1104697108

Baskin, J. M., and Baskin, C. C. (2015). Pollen (microgametophyte) competition: an assessment of its significance in the evolution of flowering plant diversity, with particular reference to seed germination. Seed Sci. Res. 25, 1-11. doi: 10.1017/S0960258515000033

Bell, P. R. (1995). Incompatibility in flowering plants: adaptation of an ancient response. Plant Cell 7, 5-16. doi: 10.1105/tpc.7.1.5

Bernhardt, P., Sage, T., Weston, P., Azuma, H., Lam, M., Thien, L. B., et al. (2003). The pollination of Trimenia moorei (Trimeniaceae): floral volatiles, insect/wind pollen vectors and stigmatic self-incompatibility in a basal angiosperm. Ann. Bot. 92, 445-458. doi: 10.1093/aob/mcg157

Boavida, L. C., Borges, F., Becker, J. D., and Feijó, J. A. (2011). Whole genome analysis of gene expression reveals coordinated activation of signaling and metabolic pathways during pollen-pistil interactions in Arabidopsis. Plant Physiol. 155, 2066-2080. doi: 10.1104/pp.110.169813

Bolinder, K., Niklas, K. J., and Rydin, C. (2015). Aerodynamics and pollen ultrastructure in Ephedra. Am. J. Bot. 102, 457-470. doi: 10.3732/ajb.14 00517

Chae, K., and Lord, E. M. (2011). Pollen tube growth and guidance: roles of small, secreted proteins. Ann. Bot. 108, 627-636. doi: 10.1093/aob/mcr015

Chandler, L. M., and Owens, J. N. (2004). The pollination mechanism of Abies amabilis. Can. J. For. Res. 34, 1071-1080. doi: 10.1139/x03-255

Chaw, S.-M., Parkinson, C. L., Cheng, Y., Vincent, T. M., and Palmer, J. D. (2000). Seed plant phylogeny inferred from all three plant genomes: monophyly of extant gymnosperms and origin of Gnetales from conifers. Proc. Natl. Acad. Sci. U.S.A. 97, 4086-4091. doi: 10.1073/pnas.97.8.4086

Chen, K.-M., Wu, G.-L., Wang, Y.-H., Tian, C.-T., Šamaj, J., Baluška, F., et al. (2008). The block of intracellular calcium release affects the pollen tube development of Picea wilsonii by changing the deposition of cell wall components. Protoplasma 233, 39-49. doi: 10.1007/s00709-008-0310-2

Chettoor, A. M., Givan, S. A., Cole, R. A., Coker, C. T., Unger-Wallace, E., Vejlupkova, Z., et al. (2014). Discovery of novel transcripts and gametophytic functions via RNA-seq analysis of maize gametophytic transcriptomes. Genome Biol. 15, 414. doi: 10.1186/s13059-014-0414-2

Choi, J. S., and Friedman, W. E. (1991). Development of the pollen-tube of Zamia furfuracea (Zamiaceae) and its evolutionary implications. Am. J. Bot. 78, 544-560. doi: 10.1093/aobpla/pls010

Coast, O., Murdoch, A. J., Ellis, R. H., Hay, F. R., and Jagadish, K. S. V. (2016). Resilience of rice (Oryza spp.) pollen germination and tube growth to temperature stress. Plant Cell Environ. 39, 26-37. doi: 10.1111/pce.12475
Costa, M., Pereira, A. M., Rudall, P. J., and Coimbra, S. (2013). Immunolocalization of arabinogalactan proteins (AGPs) in reproductive structures of an earlydivergent angiosperm, Trithuria (Hydatellaceae). Ann. Bot. 111, 183-190. doi: $10.1093 / \mathrm{aob} / \mathrm{mcs} 256$

Coulter, A., Poulis, B. A. D., and von Aderkas, P. (2012). Pollination drops as dynamic apoplastic secretions. Flora Morphol. Distrib. Funct. Ecol. Plants 207, 482-490. doi: 10.1016/j.flora.2012.06.004

Dardelle, F., Lehner, A., Ramdani, Y., Bardor, M., Lerouge, P., Driouich, A., et al. (2010). Biochemical and immunocytological characterizations of Arabidopsis pollen tube cell wall. Plant Physiol. 153, 1563-1576. doi: 10.1104/pp.110.158881

de Nettancourt, D. (2001). Incompatibility and Incongruity in Wild and Cultivated Plants. Berlin: Springer.

De-Wet, E., Robbertse, P., and Coetzer, L. (1986). Pollination and ponticulus development of Mangifera indica L. cvs Haden and Sensation. S. Afr. J. Plant Soil 3, 76-79. doi: 10.1080/02571862.1986.10634193

Distefano, G., Gentile, A., and Herrero, M. (2011). Pollen-pistil interactions and early fruiting in parthenocarpic citrus. Ann. Bot. 108, 499-509. doi: $10.1093 / \mathrm{aob} / \mathrm{mcr} 187$

Dong, J., Kim, S. T., and Lord, E. M. (2005). Plantacyanin plays a role in reproduction in Arabidopsis. Plant Physiol. 138, 778-789. doi: 10.1104/pp.105.063388

Dresselhaus, T., and Franklin-Tong, N. (2013). Male-female crosstalk during pollen germination, tube growth and guidance, and double fertilization. Mol. Plant 6, 1018-1036. doi: 10.1093/mp/sst061

Duan, Q., Kita, D., Johnson, E. A., Aggarwal, M., Gates, L., Wu, H.-M., et al. (2014). Reactive oxygen species mediate pollen tube rupture to release sperm for fertilization in Arabidopsis. Nat. Commun. 5, 3129. doi: 10.1038/ncomms4129

Endress, P. K. (1982). Syncarpy and alternative modes of escaping disadvantages of apocarpy in primitive angiosperms. Taxon 31, 48-52. doi: 10.2307/12 20588

Endress, P. K. (1996). Structure and function of female and bisexual organ complexes in gnetales. Int. J. Plant Sci. 157, S113-S125. doi: 10.1086/297407

Endress, P. K. (2011). Angiosperm ovules: diversity, development, evolution. Ann. Bot. 107, 1465-1489. doi: 10.1093/aob/mcr120

Endress, P. K. (2015). Patterns of angiospermy development before carpel sealing across living angiosperms: diversity, and morphological and systematic aspects. Bot. J. Linn. Soc. 178, 556-591. doi: 10.1111/boj.12294

Endress, P. K., and Igersheim, A. (2000). Gynoecium structure and evolution in basal angiosperms. Int. J. Plant Sci. 161, S211-S223. doi: 10.1086/317572

Erbar, C. (2003). Pollen tube transmitting tissue: place of competition of male gametophytes. Int. J. Plant Sci. 164, S265-S277. doi: 10.1086/377061

Eriksson, O., and Bremer, B. (1992). Pollination systems, dispersal modes, life forms, and diversification rates in angiosperm families. Evolution 46, 258-266. doi: $10.2307 / 2409820$

Escobar-Restrepo, J. M., Huck, N., Kessler, S., Gagliardini, V., Gheyselinck, J., Yang, W. C., et al. (2007). The FERONIA receptor-like kinase mediates malefemale interactions during pollen tube reception. Science 317, 656-660. doi: $10.1126 /$ science. 1143562

Fernando, D., Lazzaro, M., and Owens, J. (2005). Growth and development of conifer pollen tubes. Sex. Plant Reprod. 18, 149-162. doi: 10.1007/s00497-0050008-y

Ferrer, M. M., and Good, S. V. (2012). Self-sterility in flowering plants: preventing self-fertilization increases family diversification rates. Ann. Bot. 110, 535-553. doi: $10.1093 / \mathrm{aob} / \mathrm{mcs} 124$

Franklin-Tong, V. E. (2008). Self-Incompatibility in Flowering Plants. Heidelberg: Springer.

Friedman, W. E. (1987). Growth and development of the male gametophyte of Ginkgo biloba within the ovule (in vivo). Am. J. Bot. 74, 1797-1815. doi: $10.2307 / 2443963$

Friedman, W. E. (1990). Double fertilization in Ephedra, a nonflowering seedplant - its bearing on the origen of angiosperms. Science 247, 951-954. doi: $10.1126 /$ science.247.4945.951

Friedman, W. E. (1993). The evolutionary history of the seed plant male gametophyte. Trends Ecol. Evol. 8, 15-21. doi: 10.1016/0169-5347(93) 90125-9

Friedman, W. E. (2015). Development and evolution of the female gametophyte and fertilization process in Welwitschia mirabilis (Welwitschiaceae). Am. J. Bot. 102, 312-324. doi: 10.3732/ajb.1400472 
Friedman, W. E., and Carmichael, J. S. (1996). Double fertilization in Gnetales: implications for understanding reproductive diversification among seed plants. Int. J. Plant Sci. 157, S77-S94. doi: 10.1086/297405

Galati, B. G., Rosenfeldt, S., Zarlavsky, G., and Gotelli, M. M. (2016). Ultrastructure of the stigma and style of Cabomba caroliniana Gray (Cabombaceae). Protoplasma 253, 155-162. doi: 10.1007/s00709-015-0799-0

Ge, L. L., Xie, C. T., Tian, H. Q., and Russell, S. D. (2009). Distribution of calcium in the stigma and style of tobacco during pollen germination and tube elongation. Sex. Plant Reprod. 22, 87-96. doi: 10.1007/s00497-009-0094-3

Gelbart, G., and von Aderkas, P. (2002). Ovular secretions as part of pollination mechanisms in conifers. Ann. For. Sci. 59, 345-357. doi: 10.1051/forest:2002011

Gibbs, P. E. (2014). Late-acting self-incompatibility - the pariah breeding system in flowering plants. New Phytol. 203, 717-734. doi: 10.1111/nph.12874

Gilroy, S., Suzuki, N., Miller, G., Choi, W.-G., Toyota, M., Devireddy, A. R., et al. (2014). A tidal wave of signals: calcium and ROS at the forefront of rapid systemic signaling. Trends Plant Sci. 19, 623-630. doi: 10.1016/j.tplants.2014.06.013

Gonzalez, M. V., Coque, M., and Herrero, M. (1996). Pollen-pistil interaction in kiwifruit (Actinidia deliciosa; Actinidiaceae). Am. J. Bot. 83, 148-154. doi: 10.1093/aob/mcu073

Hagman, M., and Mikkola, L. (1963). Observations on cross-, self- and interspecific pollinations in Pinus peuce Griseb. Silvae Genet. 12, 73-79.

Hedhly, A. (2011). Sensitivity of flowering plant gametophytes to temperature fluctuations. Environ. Exp. Bot. 74, 9-16. doi: 10.1016/j.envexpbot.2011.03.016

Hedhly, A., Hormaza, J. I., and Herrero, M. (2003). The effect of temperature on stigmatic receptivity in sweet cherry (Prunus avium L.). Plant Cell Environ. 26, 1673-1680. doi: 10.1046/j.1365-3040.2003.01085.x

Hedhly, A., Hormaza, J. I., and Herrero, M. (2004). Effect of temperature on pollen tube kinetics and dynamics in sweet cherry, Prunus avium (Rosaceae). Am. J. Bot. 91, 558-564. doi: 10.3732/ajb.91.4.558

Hedhly, A., Hormaza, J. I., and Herrero, M. (2005a). Influence of genotypetemperature interaction on pollen performance. J. Evol. Biol. 18, 1494-1502. doi: 10.1111/j.1420-9101.2005.00939.x

Hedhly, A., Hormaza, J. I., and Herrero, M. (2005b). The effect of temperature on pollen germination, pollen tube growth, and stigmatic receptivity in peach. Plant Biol. 7, 476-483. doi: 10.1055/s-2005-865850

Hedhly, A., Hormaza, J. I., and Herrero, M. (2009). Global warming and sexual plant reproduction. Trends Plant Sci. 14, 30-36. doi: 10.1016/j.tplants.2008.11.001

Hedhly, A., Wünsch, A., Kartal, Ö., Herrero, M., and Hormaza, J. I (2015). Paternal-specific S-allele transmission in sweet cherry (Prunus avium L.): the potential for sexual selection. J. Evol. Biol. doi: 10.1111/jeb.12790 [Epub ahead of print].

Hepler, P. K., Kunkel, J. G., Rounds, C. M., and Winship, L. J. (2012). Calcium entry into pollen tubes. Trends Plant Sci. 17, 32-38. doi: 10.1016/j.tplants.2011.10.007

Herr, J. M. (1995). The origin of the ovule. Am. J. Bot. 82, 547-564. doi: $10.2307 / 2445703$

Herrero, M. (1992). From pollination to fertilization in fruit trees. Plant Growth Regul. 11, 27-32. doi: 10.1007/BF00024429

Herrero, M. (2000). Changes in the ovary related to pollen tube guidance. Ann. Bot. 85, 79-85. doi: 10.1006/anbo.1999.1014

Herrero, M. (2001). Ovary signals for directional pollen tube growth. Sex. Plant Reprod. 14, 3-7. doi: 10.1007/s004970100082

Herrero, M. (2003). Male and female synchrony and the regulation of mating in flowering plants. Philos. Trans. R. Soc. Lond. B Biol. Sci. 358, 1019-1024. doi: 10.1098/rstb.2003.1285

Herrero, M., and Arbeloa, A. (1989). Influence of the pistil on pollen tube kinetics in peach (Prunus persica). Am. J. Bot. 76, 1441-1447. doi: 10.2307/2444430

Herrero, M., and Dickinson, H. G. (1979). Pollen-pistil incompatibility in Petunia hybrida: changes in the pistil following compatible and incompatible intraspecific crosses. J. Cell Sci. 36, 1-18.

Herrero, M., and Dickinson, H. G. (1981). Pollen tube development in Petunia hybrida following compatible and incompatible intraspecific matings. J. Cell Sci. 47, 365-383.

Herrero, M., and Hormaza, J. I. (1996). Pistil strategies controlling pollen tube growth. Sex. Plant Reprod. 9, 343-347. doi: 10.1534/genetics.110.1 25286
Heslop-Harrison, J. (1975). “The adaptive significance of the exine," in The Evolutionary Significance of' the Exine, Linnean Society Symposium Series, eds J. K. Ferguson and J. Muller (London: Linnean Society of London), 27-37.

Heslop-Harrison, J., and Heslop-Harrison, Y. (1985). Surfaces and secretions in the pollen stigma interaction - a brief review. J. Cell Sci. 2, 287-300. doi: 10.1242/jcs.1985.Supplement_2.15

Heslop-Harrison, Y. (2000). Control gates and micro-ecology: the pollen-stigma interaction in perspective. Ann. Bot. 85, 5-13. doi: 10.1006/anbo.1999.1063

Higashiyama, T., and Hamamura, Y. (2008). Gametophytic pollen tube guidance. Sex. Plant Reprod. 21, 17-26. doi: 10.1007/s00497-007-0064-6

Higashiyama, T., and Takeuchi, H. (2015). The mechanism and key molecules involved in pollen tube guidance. Annu. Rev. Plant Biol. 66, 393-413. doi: 10.1146/annurev-arplant-043014-115635

Higashiyama, T., Yabe, S., Sasaki, N., Nishimura, Y., Miyagishima, S., Kuroiwa, H., et al. (2001). Pollen tube attraction by the synergid cell. Science 293, 1480-1483. doi: $10.1126 /$ science.1062429

Hill, J. P., and Lord, E. M. (1987). Dynamics of pollen tube growth in the wild radish Raphanus raphanistrum (Brassicaceae). 2. Morphology, cytochemistry and ultrastructure of transmitting tissues, and path of pollen tube growth. Am. J. Bot. 74, 988-997. doi: 10.2307/2443938

Hiscock, S. (2008). Diverse cell signalling pathways regulate pollen-stigma interactions: the search for consensus. New Phytol. 179, 286-317. doi: 10.1111/j.1469-8137.2008.02457.x

Hiscock, S., Bown, D., Gurr, S., and Dickinson, H. (2002). Serine esterases are required for pollen tube penetration of the stigma in Brassica. Sex. Plant Reprod. 15, 65-74. doi: 10.1007/s00497-002-0143-7

Hofmeister, W. (1851). Vergleichende Untersuchungen der Keimung, Entfaltung und Fruchtbildung höherer Kryptogamen (Moose, Farne, Equisetaceen, Rhizokarpeen and Lykopodiaceen) und der Samenbildung der Coniferen. Leipzig: Friedrich Hofmeister.

Hogenboom, N. G. (1975). Incompatibility and incongruity: two different mechanisms for the non-functioning of intimate partner reactions. Proc. R. Soc. Lond. B 188, 361-375. doi: 10.1098/rspb.1975.0025

Honys, D., and Twell, D. (2003). Comparative analysis of the Arabidopsis pollen transcriptome. Plant Physiol. 132, 640-652. doi: 10.1104/pp.103.020925

Hormaza, J. I., and Herrero, M. (1992). Pollen selection. Theor. Appl. Genet. 83, 663-672. doi: 10.1007/BF00226682

Hormaza, J. I., and Herrero, M. (1994). "Genetic control of self-incompatibility and reproductive development in flowering plants," in Genetic Control of SelfIncompatibility and Reproductive Development in Flowering Plants, eds E. G. Williams, A. E. Clarke, and R. B. Knox (Dordrecht: Springer Netherlands), 372-400. doi: 10.1007/978-94-017-1669-7_18

Hormaza, J. I., and Herrero, M. (1996a). Dynamics of pollen tube growth under different competition regimes. Sex. Plant Reprod. 9, 153-160. doi: 10.1007/BF02221395

Hormaza, J. I., and Herrero, M. (1996b). Male gametophytic selection as a plant breeding tool. Sci. Hortic. 65, 321-333. doi: 10.1007/BF00226682

Iwano, M., and Takayama, S. (2012). Self/non-self discrimination in angiosperm self-incompatibility. Curr. Opin. Plant Biol. 15, 78-83. doi: 10.1016/j.pbi.2011.09.003

Jin, B., Zhang, L., Lu, Y., Wang, D., Jiang, X., Zhang, M., et al. (2012). The mechanism of pollination drop withdrawal in Ginkgo biloba L. BMC Plant Biol. 12:59. doi: 10.1186/1471-2229-12-59

Joel, D. M., and Eisenstein, D. (1980). A bridge between the ovule and ovary wall in Mangifera indica L. (Anacardiaceae). Acta Bot. Neerl. 29, 203-206. doi: 10.1111/j.1438-8677.1980.tb00377.x

Johri, B. M. (1992). Haustorial role of pollen tubes. Ann. Bot. 70, 471-475.

Kasahara, R. D., Portereiko, M. F., Sandaklie-Nikolova, L., Rabiger, D. S., and Drews, G. N. (2005). MYB98 is required for pollen tube guidance and synergid cell differentiation in Arabidopsis. Plant Cell 17, 2981-2992. doi: 10.1105/tpc.105.034603

Kessler, S. A., and Grossniklaus, U. (2011). She's the boss: signaling in pollen tube reception. Curr. Opin. Plant Biol. 14, 622-627. doi: 10.1016/j.pbi.2011.07.012

Kormutak, A. (1999). Self-incompatibility in silver fir (Abies alba). Biologia 54, 101-105.

Labarca, C., and Loewus, F. (1973). The nutritional role of pistil exudate in pollen tube wall formation in Lilium longiflorum: II. Production and utilization 
of exudate from stigma and stylar canal. Plant Physiol. 52, 87-92. doi: 10.1104/pp.52.2.87

Land, W. J. G. (1907). Fertilization and embryogeny in Ephedra trifurca. Bot. Gaz. 44, 273-292. doi: 10.1086/329348

Lankinen, $\AA$, and Green, K. K. (2015). Using theories of sexual selection and sexual conflict to improve our understanding of plant ecology and evolution. $A o B$ Plants 7, lv008. doi: 10.1093/aobpla/plv008

Lausser, A., Kliwer, I., Srilunchang, K. O., and Dresselhaus, T. (2010). Sporophytic control of pollen tube growth and guidance in maize. J. Exp. Bot. 61, 673-682. doi: $10.1093 /$ jxb/erp330

Lazzaro, M., Marom, E., and Reddy, A. N. (2013). Polarized cell growth, organelle motility, and cytoskeletal organization in conifer pollen tube tips are regulated by KCBP, the calmodulin-binding kinesin. Planta 238, 587-597. doi: 10.1007/s00425-013-1919-8

Lenartowska, M., Rodríguez-García, M., and Bernarska, E. (2001). Immunocytochemical localization of esterified and unesterified pectins in unpollinated and pollinated styles of Petunia hybrida Hort. Planta 213, 182-191. doi: 10.1007/s004250000498

Leslie, A. B. (2010). Flotation preferentially selects saccate pollen during conifer pollination. New Phytol. 188, 273-279. doi: 10.1111/j.1469-8137.2010. 03356.x

Lindner, H., Kessler, S. A., Müller, L. M., Shimosato-Asano, H., Boisson-Dernier, A., and Grossniklaus, U. (2015). TURAN and EVAN mediate pollen tube reception in Arabidopsis synergids through protein glycosylation. PLoS Biol. 13:e1002139. doi: 10.1371/journal.pbio.1002139

Little, S., Prior, N., Pirone, C., and von Aderkas, P. (2014). "Pollen-ovule interaction in gymnosperms," in Reproductive Biology of Plants, eds K. G. Ramawat, J. M. Mérillon, and K. R. Shivanna (New York, NY: Taylor \& Francis), 97-117.

Liu, J., Zhang, H., Cheng, Y., Kafkas, S., and Güney, M. (2014). Pistillate flower development and pollen tube growth mode during the delayed fertilization stage in Corylus heterophylla Fisch. Plant Reprod. 27, 145-152. doi: 10.1007/s00497-014-0248-9

Lora, J., Herrero, M., and Hormaza, J. I. (2011a). Stigmatic receptivity in a dichogamous early-divergent angiosperm species, Annona cherimola (Annonaceae): influence of temperature and humidity. Am. J. Bot. 98, 265-274. doi: $10.3732 /$ ajb.1000185

Lora, J., Hormaza, J. I., Herrero, M., and Gasser, C. S. (2011b). Seedless fruits and the disruption of a conserved genetic pathway in angiosperm ovule development. Proc. Natl. Acad. Sci. U.S.A. 108, 5461-5465. doi: 10.1073/pnas.1014514108

Lora, J., Hormaza, J. I., and Herrero, M. (2010). The progamic phase of an early-divergent angiosperm, Annona cherimola (Annonaceae). Ann. Bot. 105, 221-231. doi: 10.1093/aob/mcp276

Lora, J., Hormaza, J. I., and Herrero, M. (2015). Transition from two to one integument in Prunus species: expression pattern of INNER NO OUTER (INO), ABERRANT TESTA SHAPE (ATS) and ETTIN (ETT). New Phytol. 208, 584595. doi: 10.1111/nph.13460

Losada, J., and Herrero, M. (2012). Arabinogalactan-protein secretion is associated with the acquisition of stigmatic receptivity in the apple flower. Ann. Bot. 110, 573-584. doi: 10.1093/aob/mcs116

Losada, J. M., and Herrero, M. (2014). Glycoprotein composition along the pistil of Malus $x$ domestica and the modulation of pollen tube growth. BMC Plant Biol. 14:1. doi: 10.1186/1471-2229-14-1

Losada, J. M., Herrero, M., Hormaza, J. I., and Friedman, W. E. (2014). Arabinogalactan proteins mark stigmatic receptivity in the protogynous flowers of Magnolia virginiana (Magnoliaceae). Am. J. Bot. 101, 1963-1975. doi: 10.3732/ajb. 1400280

Luza, J. G., and Polito, V. S. (1991). Porogamy and chalazogamy in walnut (Juglans regia L.). Bot. Gaz. 152, 100-106. doi: 10.1086/3 37868

Lyew, J., Li, Z., Liang-Chen, Y., Yi-bo, L., and Sage, T. L. (2007). Pollen tube growth in association with a dry-type stigmatic transmitting tissue and extragynoecial compitum in the basal angiosperm Kadsura longipedunculata (Schisandraceae). Am. J. Bot. 94, 1170-1182. doi: 10.3732/ajb.94.7.1170

Maciel-Silva, A. S., and Porto, K. C. (2014). "Reproduction in bryophytes," in Reproductive Biology of Plants, eds K. G. Ramawat, J. M. Mérillon, and K. R. Shivanna (New York, NY: Taylor \& Francis), 57-84.
Martinez-Palle, E., and Herrero, M. (1994). Male performance in pistachio (Pistacia vera). J. Hortic. Sci. 69, 1117-1122.

Martinez-Palle, E., and Herrero, M. (1998). Pollen tube pathway in chalazogamous Pistacia vera L. Int. J. Plant Sci. 159, 566-574. doi: 10.1086/2 97574

Marton, M. L., Cordts, S., Broadhvest, J., and Dresselhaus, T. (2005). Micropylar pollen tube guidance by egg apparatus 1 of maize. Science 307, 573-576. doi: 10.1126/science. 1104954

Mascarenhas, J. P. (1990). Gene activity during pollen development. Annu. Rev. Plant Physiol. Plant Mol. Biol. 41, 317-338. doi: 10.1146/annurev.pp.41.060190.001533

McInnis, S. M., Desikan, R., Hancock, J. T., and Hiscock, S. J. (2006). Production of reactive oxygen species and reactive nitrogen species by angiosperm stigmas and pollen: potential signalling crosstalk? New Phytol. 172, 221-228. doi: 10.1111/j.1469-8137.2006.01875.x

Mergen, F., Burley, J., and Furnival, G. M. (1965). Embryo and seedling development in Picea glauca (Moench) Voss after self-, cross- and windpollination. Silvae Genet. 14, 188-194.

Möller, M., Mill, R. R., Glidewell, S. M., Masson, D., Williamson, B., and Bateman, R. M. (2000). Comparative biology of the pollination mechanisms in Acmopyle pancheri and Phyllocladus hypophyllus (Podocarpaceae s. 1.). Ann. Bot. 86, 149-158. doi: 10.1006/anbo.2000.1167

Mollet, J.-C., Park, S.-Y., Nothnagel, E. A., and Lord, E. M. (2000). A lily stylar pectin is necessary for pollen tube adhesion to an in vitro stylar matrix. Plant Cell 12, 1737-1749. doi: 10.1105/tpc.12.9.1737

Mugnaini, S., Nepi, M., Guarnieri, M., Piotto, B., and Pacini, E. (2007). Pollination drop in Juniperus communis: response to deposited material. Ann. Bot. 100, 1475-1481. doi: 10.1093/aob/mcm 253

Mulcahy, D. L. (1979). The rise of the angiosperms - a genecological factor. Science 206, 20-23. doi: 10.1126/science.206.4414.20

Nepi, M., von Aderkas, P., Wagner, R., Mugnaini, S., Coulter, A., and Pacini, E. (2009). Nectar and pollination drops: how different are they? Ann. Bot. 104, 205-219. doi: 10.1093/aob/mcp124

Okuda, S., Tsutsui, H., Shiina, K., Sprunck, S., Takeuchi, H., Yui, R., et al. (2009). Defensin-like polypeptide LUREs are pollen tube attractants secreted from synergid cells. Nature 458, 357-361. doi: 10.1038/nature07882

Orban, I., and Bouharmont, J. (1995). Reproductive biology of Nymphaea capensis Thunb. var. zanzibariensis (Casp.) Verdc. (Nymphaeaceae). Bot. J. Linn. Soc. 119, 35-43. doi: 10.1111/j.1095-8339.1995.tb00727.x

Orr-Ewing, A. L. (1957). A cytological study of the effects of self-pollination on Pseudotsuga menziesii (Mirb.) Franco. Silvae Genet. 6, 179-185.

Ottaviano, E., and Mulcahy, D. L. (1989). “Genetics of angiosperm pollen," in Advances in Genetics, Vol. 26, ed. G. Meurant (Philadelphia, PA: Elsevier), 1-64. doi: 10.1016/S0065-2660(08)60222-9

Owens, J. N., Bennett, J., and L'Hirondelle, S. (2005). Pollination and cone morphology affect cone and seed production in lodgepole pine seed orchards. Can. J. For. Res. 35, 383-400. doi: 10.1139/x04-176

Owens, J. N., and Morris, S. J. (1990). Cytological basis for cytoplasmic inheritance in Pseudotsuga menziesii. 1. pollen tube and archegonial development. Am. J. Bot. 77, 433-445. doi: 10.2307/2444377

Owens, J. N., Takaso, T., and Runions, C. J. (1998). Pollination in conifers. Trends Plant Sci. 3, 479-485. doi: 10.1016/S1360-1385(98)01337-5

Pacini, E., Franchi, G. G., and Ripaccioli, M. (1999). Ripe pollen structure and histochemistry of some gymnosperms. Plant Syst. Evol. 217, 81-99. doi: 10.1007/BF00984923

Palanivelu, R., Brass, L., Edlund, A. F., and Preuss, D. (2003). Pollen tube growth and guidance is regulated by $\mathrm{POP} 2$, an Arabidopsis gene that controls GABA levels. Cell 114, 47-59. doi: 10.1016/s0092-8674(03) 00479-3

Palanivelu, R., and Tsukamoto, T. (2012). Pathfinding in angiosperm reproduction: pollen tube guidance by pistils ensures successful double fertilization. Wiley Interdiscip. Rev. Dev. Biol. 1, 96-113. doi: 10.1002/ wdev.6

Park, S. Y., Jauh, G. Y., Mollet, J. C., Eckard, K. J., Nothnagel, E. A., Walling, L. L., et al. (2000). A lipid transfer-like protein is necessary for lily pollen tube adhesion to an in vitro stylar matrix. Plant Cell 12, 151-163. doi: $10.2307 / 3871036$ 
Pereira, A., Pereira, L., and Coimbra, S. (2015). Arabinogalactan proteins: rising attention from plant biologists. Plant Reprod. 28, 1-15. doi: 10.1007/s00497015-0254-6

Pontieri, V., and Sage, T. L. (1999). Evidence for stigmatic self-incompatibility, pollination induced ovule enlargement and transmitting tissue exudates in the paleoherb, Saururus cernuus L. (Saururaceae). Ann. Bot. 84, 507-519. doi: 10.1006/anbo.1999.0947

Potocký, M., Jones, M. A., Bezvoda, R., Smirnoff, N., and Žárský, V. (2007). Reactive oxygen species produced by NADPH oxidase are involved in pollen tube growth. New Phytol. 174, 742-751. doi: 10.1111/j.1469-8137.2007.02042.x

Prychid, C. J., Sokoloff, D. D., Remizowa, M. V., Tuckett, R. E., Yadav, S. R., and Rudall, P. J. (2011). Unique stigmatic hairs and pollen-tube growth within the stigmatic cell wall in the early-divergent angiosperm family Hydatellaceae. Ann. Bot. 108, 599-608. doi: 10.1093/aob/mcr021

Qin, Y., Chen, D., and Zhao, J. (2007). Localization of arabinogalactan proteins in anther, pollen, and pollen tube of Nicotiana tabacum L. Protoplasma 231, 43-53. doi: 10.1007/s00709-007-0245-Z

Qu, L.-J., Li, L., Lan, Z., and Dresselhaus, T. (2015). Peptide signalling during the pollen tube journey and double fertilization. J. Exp. Bot. 66, 5139-5150. doi: 10.1093/jxb/erv275

Rafińska, K., Świdziński, M., and Bednarska-Kozakiewicz, E. (2014). Homogalacturonan deesterification during pollen-ovule interaction in Larix decidua Mill.: an immunocytochemical study. Planta 240, 195-208. doi: 10.1007/s00425-014-2074-6

Rodrigo, J., Hormaza, J. I., and Herrero, M. (2000). Ovary starch reserves and flower development in apricot (Prunus armeniaca). Physiol. Plant. 108, 35-41. doi: 10.1034/j.1399-3054.2000.108001035.x

Rothwell, G. W. (1972). Evidence of pollen tubes in paleozoic pteridosperms. Science 175, 772-774. doi: 10.1126/science.175.4023.772

Rudall, P. J., and Bateman, R. M. (2007). Developmental bases for key innovations in the seed-plant microgametophyte. Trends Plant Sci. 12, 317-326. doi: 10.1016/j.tplants.2007.06.004

Rydin, C., and Bolinder, K. (2015). Moonlight pollination in the gymnosperm Ephedra (Gnetales). Biol. Lett. 11, 20140993. doi: 10.1098/rsbl.2014.0993

Sage, T. L., Bagha, S., Lundsgaard-Nielsen, V., Branch, H. A., Sultmanis, S., and Sage, R. F. (2015). The effect of high temperature stress on male and female reproduction in plants. Field Crop. Res. 182, 30-42. doi: 10.1016/j.fcr.2015.06.011

Sage, T. L., and Sampson, F. B. (2003). Evidence for ovarian self-incompatibility as a cause of self-sterility in the relictual woody angiosperm, Pseudowintera axillaris (Winteraceae). Ann. Bot. 91, 807-816. doi: 10.1093/aob/mcg085

Sanzol, J., and Herrero, M. (2001). The "effective pollination period" in fruit trees. Sci. Hortic. 90, 1-17. doi: 10.1016/S0304-4238(00)00252-1

Sanzol, J., Rallo, P., and Herrero, M. (2003). Asynchronous development of stigmatic receptivity in the pear (Pyrus communis; Rosaceae) flower. Am. J. Bot. 90, 78-84. doi: 10.3732/ajb.90.1.78

Sargent, R. D., and Otto, S. P. (2004). A phylogenetic analysis of pollination mode and the evolution of dichogamy in angiosperms. Evol. Ecol. Res. 6, 1183-1199.

Sawada, H., Morita, M., and Iwano, M. (2014). Self/non-self recognition mechanisms in sexual reproduction: new insight into the self-incompatibility system shared by flowering plants and hermaphroditic animals. Biochem. Biophys. Res. Commun. 450, 1142-1148. doi: 10.1016/j.bbrc.2014.05.099

Seavey, S., and Bawa, K. (1986). Late-acting self-incompatibility in angiosperms. Bot. Rev. 52, 195-219. doi: 10.1007/BF02861001

Sedgley, M., and Annells, C. M. (1981). Flowering and fruit-set response to temperature in the avocado cultivar Hass. Sci. Hortic. 14, 27-33. doi: 10.1016/0304-4238(81)90075-3

Sedgley, M., and Griffin, A. R. (1989). Sexual Reproduction of Tree Crops. Cambridge, MA: Academic Press.

Serrano, I., Romero-Puertas, M. C., Sandalio, L. M., and Olmedilla, A. (2015). The role of reactive oxygen species and nitric oxide in programmed cell death associated with self-incompatibility. J. Exp. Bot. 66, 2869-2876. doi: 10.1093/jxb/erv083

Skinner, D., and Gasser, C. S. (2009). Expression-based discovery of candidate ovule development regulators through transcriptional profiling of ovule mutants. BMC Plant Biol. 9:29. doi: 10.1186/1471-2229-9-29
Smith-Huerta, N. L. (1991). Branching pollen tubes in the genus Clarkia, an evolutionary response to viscin threads. Evol. Trends Plants 5, $125-130$.

Sogo, A., and Tobe, H. (2005). Intermittent pollen-tube growth in pistils of alders (Alnus). Proc. Natl. Acad. Sci. U.S.A. 102, 8770-8775. doi: 10.1073/pnas.0503081102

Sogo, A., and Tobe, H. (2006a). Delayed fertilization and pollen-tube growth in pistils of Fagus japonica (Fagaceae). Am. J. Bot. 93, 1748-1756. doi: 10.3732/ajb.93.12.1748

Sogo, A., and Tobe, H. (2006b). Mode of pollen-tube growth in pistils of Myrica rubra (Myricaceae): a comparison with related families. Ann. Bot. 97, 71-77. doi: $10.1093 / \mathrm{aob} / \mathrm{mcj} 015$

Southworth, D., and Cresti, M. (1997). Comparison of flagellated and nonflagellated sperm in plants. Am. J. Bot. 84, 1301-1311. doi: 10.2307/24 46056

Steinhorst, L., and Kudla, J. (2013). Calcium - a central regulator of pollen germination and tube growth. Biochim. Biophys. Acta 1833, 1573-1581. doi: 10.1016/j.bbamcr.2012.10.009

Stephenson, A. G., Travers, S. E., Mena-Ali, J. I., and Winsor, J. A. (2003). Pollen performance before and during the autotrophic-heterotrophic transition of pollen tube growth. Philos. Trans. R. Soc. Lond. B Biol. Sci. 358, 1009-1017. doi: 10.1098/rstb.2003.1290

Sterling, C. (1963). Structure of male gametophyte in gymnosperms. Biol. Rev. Camb. Philos. Soc. 38, 167-203. doi: 10.1111/j.1469-185X.1963.tb00 782.x

Suárez, C., Zienkiewicz, A., Castro, A., Zienkiewicz, K., Majewska-Sawka, A., and Rodríguez-García, M. (2013). Cellular localization and levels of pectins and arabinogalactan proteins in olive (Olea europaea L.) pistil tissues during development: implications for pollen-pistil interaction. Planta 237, 305-319. doi: 10.1007/s00425-012-1774-z

Takaso, T., vonAderkas, P., and Owens, J. N. (1996). Prefertilization events in ovules of Pseudotsuga: ovular secretion and its influence on pollen tubes. Can J. Bot. 74, 1214-1219. doi: 10.1139/b96-146

Takayama, S., and Isogai, A. (2005). Self-incompatibility in plants. Annu. Rev. Plant Biol. 56, 467-489. doi: 10.1146/annurev.arplant.56.032604.1 44249

Takeuchi, H., and Higashiyama, T. (2012). A species-specific cluster of defensin-like genes encodes diffusible pollen tube attractants in Arabidopsis. PLoS Biol. 10:e1001449. doi: 10.1371/journal.pbio.10 01449

Taylor, D. W., and Kirchner, G. (1996). "The origin and evolution of the angiosperm carpel," in Flowering Plant Origin, Early Evolution and Phylogeny, eds D. W. Taylor and L. J. Hickey (New York, NY: Chapman and Hall), $116-140$.

Thien, L. B., Sage, T. L., Jaffre, T., Bernhardt, P., Pontieri, V., Weston, P. H., et al. (2003). The population structure and floral biology of Amborella trichopoda (Amborellaceae). Ann. Miss. Bot. Gard. 90, 466-490. doi: 10.2307/32 98537

Traverso, J. A., Pulido, A., Rodríguez-García, M. I., and Alché, J. D. (2013). Thiol-based redox regulation in sexual plant reproduction: new insights and perspectives. Front. Plant Sci. 4:465. doi: 10.3389/fpls.2013. 00465

Villar, M., Knox, R. B., and Dumas, C. (1984). Effective pollination period and nature of pollen-collecting apparatus in the gymnosperm, Larix leptolepis. Ann. Bot. 53, 279-284.

von Aderkas, P., Prior, N., Gagnon, S., Little, S., Cross, T., Hardie, D., et al. (2015). Degradome and secretome of pollination drops of Ephedra. Bot. Rev. 81, 1-27. doi: 10.1007/s12229-014-9 $147-\mathrm{x}$

Wang, H. Z., Boavida, L. C., Ron, M., and McCormick, S. (2008). Truncation of a protein disulfide isomerase, PDIL2-1, delays embryo sac maturation and disrupts pollen tube guidance in Arabidopsis thaliana. Plant Cell 20, 3300-3311. doi: $10.1105 /$ tpc.108.062919

Wang, X.-F., Armbruster, W. S., and Huang, S.-Q. (2012). Extra-gynoecial pollen-tube growth in apocarpous angiosperms is phylogenetically widespread and probably adaptive. New Phytol. 193, 253-260. doi: 10.1111/j.14698137.2011.03912.x 
Whitehead, D. R. (1969). Wind pollination in angiosperms - evolutionary and environmental considerations. Evolution 23, 28-35. doi: 10.2307/24 06479

Williams, C. G., Zhou, Y., and Hall, S. E. (2001). A chromosomal region promoting outcrossing in a conifer. Genetics 159, 1283-1289.

Williams, E. G., Knox, B. R., and Rouse, J. L. (1982). Pollination sub-systems distinguished by pollen tube arrest after incompatible interspecific crosses in Rhododendron (Ericaceae). J. Cell Sci. 53, $255-277$.

Williams, J. H. (2008). Novelties of the flowering plant pollen tube underlie diversification of a key life history stage. Proc. Natl. Acad. Sci. U.S.A. 105, 11259-11263. doi: 10.1073/pnas.0800036105

Williams, J. H. (2009). Amborella trichopoda (Amborellaceae) and the evolutionary developmental origins of the angiosperm progamic phase. Am. J. Bot. 96, 144-165. doi: 10.3732/ajb.0800070

Williams, J. H. (2012a). Pollen tube growth rates and the diversification of flowering plant reproductive cycles. Int. J. Plant Sci. 173, 649-661. doi: $10.1086 / 665822$

Williams, J. H. (2012b). The evolution of pollen germination timing in flowering plants: Austrobaileya scandens (Austrobaileyaceae). AoB Plants 2012, ls010. doi: 10.1093/aobpla/pls010
Williams, J. H., McNeilage, R. T., Lettre, M. T., and Taylor, M. L. (2010). Pollen tube growth and the pollen-tube pathway of Nymphaea odorata (Nymphaeaceae). Bot. J. Linn. Soc. 162, 581-593. doi: 10.1111/j.1095-8339.2010. 01039. $\mathrm{x}$

Wilms, H. J. (1974). "Branching of pollen tubes in spinach," in Fertilization in Higher Plants, ed. H. F. Linskens (Amsterdam: North Holland Publishing Company), 155-160.

Zavada, M. S., and Taylor, T. N. (1986). The role of self-incompatibility and sexual selection in the gymnosperm-angiosperm transition - a hypothesis. Am. Nat. 128, 538-550. doi: $10.1086 / 284586$

Conflict of Interest Statement: The authors declare that the research was conducted in the absence of any commercial or financial relationships that could be construed as a potential conflict of interest.

Copyright (c) 2016 Lora, Hormaza and Herrero. This is an open-access article distributed under the terms of the Creative Commons Attribution License (CC BY). The use, distribution or reproduction in other forums is permitted, provided the original author(s) or licensor are credited and that the original publication in this journal is cited, in accordance with accepted academic practice. No use, distribution or reproduction is permitted which does not comply with these terms. 